JAMP: Jurnal Adminitrasi dan Manajemen Pendidikan

Volume 3 Nomor 2 Juni 2020, Hal : 182-191

Tersedia Online di http://journal2.um.ac.id/index.php/jamp/

ISSN 2615-8574 (online)

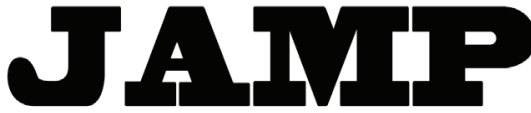

JURNAL ADMINISTRASI DAN MANAJEMEN PENDIDIKAN

\title{
IMPLEMENTASI PENDIDIKAN KARAKTER SOPAN SANTUN MELALUI PEMBELAJARAN AKIDAH AKHLAK
}

\author{
Fernanda Rahmadika Putra \\ Ali Imron \\ Djum Djum Noor Benty \\ Universitas Negeri Malang \\ J1. Semarang, No. 5 Malang \\ putrafernanda26@gmail.com
}

\begin{abstract}
Abstrak: Pentingnya adanya pendidikan karakter dikarenakan melalui pendidikan karakter itu bisa menumbuhkan kecerdasan, kecakapan, dan kemampuan siswa. Fokus penelitian ini adalah: (1) pembelajaran Akidah Akhlak, (2) bentuk perilaku pendidikan karakter sopan santun, (3) penanaman pendidikan karakter sopan santun, (4) faktor penunjang penanaman pendidikan karakter sopan santun , (5) pengoptimalan pendayagunaan faktor penunjang penanaman pendidikan karakter sopan santun , (6) faktor kendala dalam penanaman pendidikan karakter sopan santun, (7) solusi dari kendala penanaman pendidikan karakter sopan santun. Simpulan penelitian ini: (1) pembelajaran Akidah Akhlak pada kegiatan belajar mengajar berjalan dengan lancar, efektif, dan inovatif, (2) bentuk perilaku pendidikan karakter sopan santun sudah ada pembentukan, tinggal menambah dari kekurangan yang ada, (3) penanaman pendidikan karakter sopan santun Bapak dan Ibu Guru memberikan contoh sikap yang mulia, memberi dorongan, dan membiasakan perilaku yang mulia, (4) faktor penunjang dalam penanaman pendidikan karakter sopan santun yakni didukung oleh sarana prasarana kelas yang baik dan memadai dan minat belajar siswa yang tinggi,(5) pengoptimalan pendayagunaan faktor penunjang penanaman pendidikan karakter pihak sekolah harus bisa bertanggungjawab dalam mengembangkan penanaman pendidikan karakter sopan santun yang mulia, (6) faktor kendala yang ditemui dalam penanaman pendidikan karakter sopan santun yaitu faktor lingkungan, keberagaman peserta didik, salah dalam memilih teman, (7) ) solusi yang dilakukan dari kendala penanaman pendidikan karakter yakni memberi nasihat, memberi hukuman atau teguran berupa peringatan.
\end{abstract}

Kata kunci: implementasi, pendidikan karakter, sopan santun, akidah akhlak

Abstract: The importance of character education is because through character education it can foster students' intelligence, skills and abilities. The focus of this study are: (1) learning the moral code, (2) the form of behavior education character manners, (3) inculcation of character education polite, (4) supporting factors inculcation of character education manners, (5) optimizing the utilization of the supporting factors of planting courtesy character education, (6) constraints factors in the cultivation of character education courtesy, (7) solutions to the constraints of character education cultivation courtesy. The conclusions of this study: (1) learning of the moral code in teaching and learning activities run smoothly, effectively, and innovatively, (2) the forms of character education behavior have been formed, just add to the shortcomings, (3) inculcation of polite character education polite Mr. and Mrs. Teachers give examples of noble attitudes, give encouragement, and familiarize noble behavior, (4) supporting factors in the cultivation of polite character education that is supported by good and adequate classroom infrastructure and high student interest in learning, (5 ) optimizing the utilization of supporting factors for the planting of character education in schools must be able to be responsible in developing the cultivation of noble character education education, 
(6) the constraint factors encountered in the planting of polite character education namely environmental factors, diversity of students, wrong in choosing friends, (7)) the solution made from the constraints of planting education $\mathrm{n}$ character that is giving advice, giving punishment or warning in the form of a warning.

Keywords: implementation, character education, manners, moral theology

Pengintegrasian pendidikan karakter sopan santun dalam kegiatan pembelajaran, dalam penelitian Mufti'ah (2017:119) yaitu bisa menggunakan model pendidikan karakter dengan melakukan perencanaan dalam kegiatan belajar mengajar, proses kegiatan belajar mengajar, dan penilaian hasil pembelajaran. Pengintegrasian pendidikan karakter pada mata pelajaran Akidah Akhlak yakni dengan memasukkan nilai-nilai karakter pada proses kegiatan belajar mengajar dengan mengaplikasikan pembiasaan, penanaman nilai, dan keteladanan. Pada pembinaan pendidikan karakter guru di madrasah harus melakukannya melalui sikap teladan, peringatan, nasihat, dan sanksi tegas, pada pembinaan sikap sopan peserta didik diharapkan para peserta didik akan mempunyai sikap perilaku yang teladan dimanapun ia berada. Karakter inidividu dapat dilihat dari tiga aspek, menurut Listyanti (2012:3) yaitu: mencintai perilaku kebaikan ,mengetahui kebaikan dan melaksanakan kebaikan. Pendidikan karakter sopan santun adalah suatu proses pendidikan yang bertujuan guna menjadikan pribadi individu kedalam arah yang jauh lebih baik yakni dengan pendidikan budi pakerti yang nantinya dapat dicerminkan dalam etika, perbuatan secara nyata yakni tingkah laku yang mulia.

Berdasarkan hasil observasi awal yang dilakukan peneliti di MI Sunan Kalijogo Malang masih banyak peserta didik yang tidak mencerminkan perilaku atau sikap sopan santun yang baik terhadap Bapak dan Ibu Guru maupun sesama teman-temannya, beberapa juga ada peserta didik yang menyangkal pada saat diberi nasihat oleh Bapak dan Ibu Guru, beberapa masih ada peserta didik yang tidak meminta izin atau berbicara langsung kepada Bapak atau Ibu Guru pada saat ia sedang masuk ataupun keluar dari ruang kelas, pada saat betutur kata beberapa ada juga peserta didik enggan menggunakan bahasa yang baik (santun) dan juga ada peserta didik banyak yang berani berani melawan Bapak atau Ibu Guru pada saat kegiatan belajar mengajar berlangsung.

Fokus penelitian ini adalah: (1) pembelajaran Akidah Akhlak, (2) bentuk perilaku pendidikan karakter sopan santun, (3) penanaman pendidikan karakter sopan santun, (4) faktor penunjang penanaman pendidikan karakter sopan santun , (5) pengoptimalan pendayagunaan faktor penunjang penanaman pendidikan karakter sopan santun , (6) faktor kendala dalam penanaman pendidikan karakter sopan santun, (7) solusi dari kendala penanaman pendidikan karakter sopan santun.

Tujuan penelitian ini adalah: (1) mendeskripsikan pembelajaran Akidah Akhlak, (2) mendeskripsikan bentuk perilaku pendidikan karakter sopan santun, (3) mendeskripsikan penanaman pendidikan karakter sopan santun, (4) mendeskripsikan faktor penunjang penanaman pendidikan karakter sopan santun , (5) mendeskripsikan pengoptimalan pendayagunaan faktor penunjang penanaman pendidikan karakter sopan santun , (6) mendeskripsikan faktor kendala dalam penanaman pendidikan karakter sopan santun, (7) mendeskripsikan solusi dari kendala penanaman pendidikan karakter sopan santun.

\section{METODE}

Pendekatan dalam penelitian ini adalah pendekatan kualitatif, dengan menggunakan jenis penelitian studi kasus deskriptif, penelitian ini dilakukan di MI Sunan Kalijogo Malang dengan menggunakan teknik pengumpulan data berupa observasi atau pengamatan, wawancara, dan dokumentasi. Wawancara ditujukan kepada Kepala Sekolah, guru mata pelajaran akidah akhlak, dan beberapa peserta didik kelas V. Pengumpulan data diperoleh peneliti dari hasil pengumpulan data, reduksi data, penyajian data, dan memverifikasi data. Penelitian ini menggunakan pengecekan keabsahan data, yang berguna memeriksa tingkat kebenaran dari data yang sudah diteliti, peneliti menerapkan ketekunan pengamatann, triangulasi, dan pengecekan anggota. 


\section{HASIL}

\section{Pembelajaran Akidah Akhlak}

Pembelajaran akidah akhlak di MI Sunan Kalijogo Malang ada 3 aspek dalam pelaksanaannya, adalah sebagai berikut: (1) Aspek persiapan yakni dalam pelaksanaan kegiatan belajar mengajar berlangsung Ibu guru membuka pelajaran dengan memberika salam terlebih dahulu dan doa. Lalu, peserta didik menjawab salam dari Ibu guru, (2) Aspek pelaksanaan yaitu setelah melalui tahap persiapan yang matang maka pada tahap selanjutnya yaitu tahap pelaksanaan, yakni tahap pelaksanaan pembelajaran, dalam mengajar peserta didik diajak untuk mencermati beberapa gambar yang terdapat pada buku, kemudian ibu guru memberikan kesempatan terhadap para peserta didik agar menyampaikan komentarnya dengan mengacungkan jari. Kemudian ibu guru meminta pendapat beberapa peserta didik terkait materi yang dijelaskan, kemudian ibu guru menerangkan apa itu berbicara kotor dan menulisnya dipapan tulis, (3) Aspek penutup yaitu guru bersama peserta didik menyimpulkan tentang pengertian berbicara kotor dan akibatnya, guru meminta peserta didik untuk menerapkannya di rumah masing-masing.

\section{Bentuk Perilaku Pendidikan Karakter Sopan Santun}

Bentuk perilaku pendidikan karakter sopan santun bagi peserta didik di MI Sunan Kalijogo Malang yakni dalam pembentukan karakter yang mulanya masih rendah menjadi yang lebih baik lagi, guna dapat terbentuknya kepribadian yang bermartabat pada diri peserta didik. Bentuk perilaku pendidikan karakter sopan santun peserta didik ada yang sudah bisa menerapkannya dengan baik, adapula yang masih belum menerapkannya. Bentuk perilaku pendidikan karakter yang sudah dilaksanakan dengan baik yakni: (1) Selalu berpakaian rapi, (2) Selalu menyapa teman nya, (3) Ikut dalam kegiatan pembiasaan rutin sholat dhuha, (4) Selalu bertutur kata yang baik.

Adapun untuk bentuk perilaku pendidikan karakter yang belum dilaksanakan dengan baik yakni: (1) Beberapa ada peserta didik yang kurang sopan dari perilakunya, (2) Beberapa ada peserta didik yang tidak mentaati peraturan yang ada disekolah, (3) Sebagian beberapa ada yang membuang sampah tidak pada tempatnya, (4) Beberapa peserta didik masih ada yang berbicara kotor.

\section{Penanaman Pendidikan Karakter Sopan Santun}

Guna mempermudah dalam merealisasikan tujuan pendidik untuk mengintegarasikan penanaman pendidikan karakter kearah yang lebih baik, pada dasarnya pembentukan karakter dilakukan dengan unsur keteladanan dan pembiasaan bersikap mulia yang disandarkan pada tingkah laku guru. Untuk menanamkan karakter dalam diri peserta didik khususnya sikap sopan santun tersebut, dilaksanakan melakukan pembiasaan rutin untuk mencetak perilaku peserta didik yang mulia, selain itu melalui keteladanan yang diperoleh dari lingkungan keluarga, dengan demikian peserta didik akan memiliki sikap atau perilaku teladan yang baik, beretika sesuai norma, dan lain sebagainya. Adapun yang dilakukan dalam penanaman pendidikan karakter sopan santun di MI Sunan Kalijogo Malang yaitu: (1) Pembiasaan pagi seperti sholat dhuha dan dhuhur berjama'ah, bersalaman dengan bapak atau ibu guru, membaca asmaul husna, selalu berbaris sebelum masuk kelas, (2) Keteladanan baik yang diperoleh dari lingkungan peserta didik, (3) Keluhuran moral, kematangan mental dan pengetahuan, (4) Perilaku sopan santun yang dicontohkan dari guru.

\section{Faktor Penunjang Penanaman Pendidikan Karakter Sopan Santun}

Faktor yang menujang pada penanaman pendidikan karakter sopan santun pada peserta didik di MI Sunan Kalijogo Malang yakni: (1) Sarana pendidikan seperti Masjid yang dapat digunakan peserta didik untuk melaksanakan sholat dhuha berjama'ah, (2) Prasarana pendidikan seperti setiap kelas ada LCD yang dapat membuat peserta didik tidak mudah bosan pada kegiatan belajar mengajar, (3) Minat belajar peserta didik, (4) Kegiatan pengembangan peserta didik diluar kegiatan belajar mengajar seperti adanya ekstrakurikuler, (5) Perhatian guru terhadap akhlak peserta didik, (6) Budaya sekolah yang membiasakan peserta didik untuk selalu bertutur kata sopan dan santun dimanapun ia berada. 


\section{Pengoptimalan Pendayagunaan Faktor Penunjang Penanaman Pendidikan Karakter Sopan Santun}

Penerapan pendidikan karakter melalui kegiatan belajar mengajar Akidah Akhlak dikelas maupun diluar kegiatan mengajar tersebut harus dapat dilaksanakan dengan tepat sasaran, untuk mengoptimalkan pendayagunaan faktor penunjang penanaman pendidikan karakter sopan sanun yaitu: (1) Dukungan Moral dari Bapak dan Ibu guru, (2) Guru selalu memberikan contoh atau keteladanan baik pada peserta didik, (3) Aktivitas religi peserta didik, (4) Pembiasaan pagi.

Selain itu semua guru mata pelajaran harus tahu bagaimana mengarahkan keberhasilan pendidikan karakter peserta didik, guru harus memberikan contoh atau keteladanan perilaku yang baik terhadap peserta didik, membiasakan sholat dhuha berjama'ah di masjid, dalam hal kegiatan pembelajaran diawali dengan membaca doa bersama, membaca asmaul husna bersama, selalu berdoa bersama sebelum kegiatan belajar mengajar dimulai, selalu bersalaman dengan bapak/ibu guru setelah sholat dhuha dan sholat dhuhur.

\section{Faktor Kendala dalam Penanaman Pendidikan Karakter Sopan Santun}

Faktor kendala implementasi pendidikan karakter sopan santun di MI Sunan Kalijogo Malang yakni: (1) Kedudukan orang tua peserta didik yang kurang andil dalam hal pembentukan sikap atau etika, (2) Adanya pergaulan bebas peserta didik, (3) Kurangnya perhatian secara khusus beberapa guru terhadap perilaku peserta didik, (4) Latar belakang kehidupan antar peserta didik yang tidak sama, (5) Masih ada beberapa peserta didik yang masih sulit ketika diberi nasihat dari bapak atau ibu guru, (6) Masih ada beberapa peserta didik yang belum bertutur kata sopan, (7) Lingkungan rumah yakni masih kurang mendukung perkembangan anaknya di sekolah karena bagi orang tua tersebut pelajaran disekolah sudah cukup sehingga tidak ada pantuan secara khusus dari orangtua, (8) Kurangnya perhatian guru terhadap perilaku peserta didik.

\section{Solusi dari Kendala Penanaman Pendidikan Karakter Sopan Santun}

Adapun cara mengatasi solusi yang dilakukan dari kendala penanaman pendidikan karakter sopan santun pada mata pelajaran Akidah Akhlak adalah sebagai berikut: (1) Menegur yakni supaya peserta didik bisa bersikap santun ketika mau sholat, ketika menghadap guru, ketika lewat didepan orang tua, (2) Memberi nasihat tanpa melakukan kekerasan fisik yakni guru memberi nasihat kepada peserta didik yang tidak sopan santun terhadap perilakunya, (3) Mengadakan sosialisasi, yaitu pada saat pengambilan raport kita tekankan kepada wali murid bahwa jika berada di sekolah harus memiliki sikap sopan santun yang tinggi, (4) Memberi hukuman yang sifatnya mendidik seperti harus menghafalkan surat pendek di al'quran, (5) Selalu membiasakan kepada peserta didik untuk membaca doa jika mau masuk ataupun keluar ruang kelas, (6) Selalu membiasakan agar menyapa bapak atau ibu guru ketika berjumpa baik didalam sekolah maupun diluar sekolah, (7) membiasakan budaya untuk berperilaku 5S yakni: Senyum, Sapa, Salam, Sopan dan Santun.

\section{PEMBAHASAN}

\section{Pembelajaran Akidah Akhlak}

Kegiatan belajar mengajar Akidah Akhlak berisikan tentang kisah tauladan atau perilaku mulia sesuai dengan norma yang diintegrasikan pada pemahaman dan pendalaman akan asmaul husna, dan menciptakan suasana teladan dan pembiasaan etika guna menanamkan perilaku mulia dengan memberikan contoh etika atau sikap dalam pengamalannya di kehidupannya. Adapun pelaksanaan kegiatan - kegiatan pembelajaran menggunakan metode pembelajaran yakni metode ceramah, tanya jawab, demonstrasi dan pembiasaan. Jadi pemilihan metode pembelajaran pun disesuaikan dengan materi yang sedang diajarkan pada hari itu. Untuk penggunaan media yang dipakai pada proses kegiatan belajar mengajar yakni menggunakan komponen suara dan komponen gambar yaitu LCD proyekor dan kertas yang sudah dibuat oleh guru dan dipotong kecil-kecil dan ditempelkan di papan tulis berisi point-point materi, karena dengan adanya media tersebut peserta didik bisa tertarik pada pembelajaran. 
Hal tersebut sesuai dengan pendapat Sumantri (2016: 115) bahwa dalam sebuah proses pembelajaran di kelas, yang harus dimiliki adalah pengetahuan dan pemahaman yang cukup dalam media pembelajaran, yang meliputi antara lain: (a) media pembelajaran sebagai alat komunikasi yang digunakan untuk meningkatkan keefektifan proses belajar mengajar dikelas; (b) media berfungsi dalam hal mencapai tujuan pendidikan; (c) pemilihan dan penggunaan sebuah media pembelajaran; (d) berbagai jenis alat dan teknik media pembelajaran di kelas; (e) media pembelajaran dalam setiap mata pelajaran yang diajarkan di kelas; (f) usaha adanya inovasi dalam media pembelajaran.

Metode dalam pembelajaran Akidah Akhlak itu penting, dengan adanya metode pembelajaran maka dalam pelaksanannya akan mampu menambah keberhasilan suatu pembelajaran dan meningkatkan semangat belajar yang tingi pada saat kegiatan belajar mengajar berlangsung. Adapun pelaksanaan dalam kelas metode yang digunakan di MI Sunan Kalijogo Malang adalah metode ceramah, berdiskusi dengan peserta ddik lain, tanya jawab, dan kegiatan rutin pembiasaan pagi. Metode kegiatan belajar mengajar yang digunakan pada saat pembelajaran mata pelajaran akidah akhlak menyesuaikan dengan materi yang dipelajarinya. Hal tersebut sesuai dengan pendapat Suprahatiningrum (2013: 153) bahwa sebuah metode pembelajaran pada intinya merupakan rancangan yang diarahkan guna mencapai tujuan yang diinginkan. Seperti metode yang dapat menjaminkan setiap peserta didik untuk mencapai tujuan yang diinginkan dari kegiatan belajar mengajar itu sendiri. Adapun cara yang dapat diimplementasikan untuk menerapkan metode yang sudah tersusun yaitu dengan kegiatan nyata, supaya tujuan yang telah disusun atau direncanakan dapat tercapai dengan optimal, baik kaidahnya maupun perangkat sarana yang digunakan guna membantu pelaksanaan strategi kegiatan belajar mengajar tersebut. Paparan tersebut menggambarkan bahwa diperlukan metode pembelajaran yang bervariasi sesuai dengan situasi dan kondisi agar suatu kegiatan belajar mengajar dapat berjalan secara efektif, efisien dan tidak membosankan. Dari beberapa metode yang ada masing-masing terdapat keunggulan maupun kekurangan. Disini peran seorang guru yakni dapat memilah diantara keragaman beberapa metode yang cocok untuk menghasilkan iklim kegiatan belajar mengajar yang efisien efektif dan menyenangkan yaikni seperti menggunkan metode ceramah, berdiskusi dengan temannya, demonstrasi, karya wisata dan lain sebagainya.

\section{Bentuk Perilaku Pendidikan Karakter Sopan Santun}

Berdasarkan hasil penelitian yang dilakukan, bahwasanya perilaku sopan santun peserta didik di MI Sunan Kalijogo Malang karakter sopan santun peserta didik sudah baik dan sudah ada pembentukan tinggal menambah. Perilaku merupakan suatu tindakan yang bertujuan untuk memperbaiki sikap seseorang individu menuju kearah yang lebih mulia. Perubahan sikap yang ada tidak dapat terjadi secara instan melainkan terdapat pengaruh dari lingkungan yang akan mempengaruhi sikap stersebut. Pendidikan karakter peserta didik sudah memuat nilai-nilai kompetitif yang harus dikembangkan, sebagaimana yang diungkapkan oleh Imron (2016:492) bahwa nilai-nilai kompetitif yang diintegrasikan dalam pengelolaan karakter peserta didik meliputi: kepribadian, ketekunan penuh gairah, pantang menyerah, kerjasama, inovasi atau agen perubahan, produktif, sadar akan kualitas, berorientasi secara global, belajar tanpa batas, penuh syukur. Di MI Sunan Kalijogo Malang guna menangani sikap sopan santun peserta didik, tiap tenaga pendidik memiliki metode sendiri dalam menangani sikap peserta didik yang akhlaknya bisa dibilang masih rendah. Hal ini juga diungkapkan oleh Guru Akidah Akhlak bahwa untuk mengatasi sikap peserta didik yang akhlaknya masih rendah yakni menasehatinya dengan halus dan memberuikan contoh bagaimana sikap yang baik dalam bertindak. Apabila sudah diberi nasehat dan tidak ada perubahan sikap dari peserta didik, maka sekolah mengpasrahkan kepada orang tua peserta didik agar ia memberikan bimbingan atau binaan kepada peserta didik secara sungguh-sungguh, dikarenakan biasanya para peserta didik bisa dipengaruhi dari lingkunga rumahnya. Menurut Zuhriyah (2007:87) merubah perilaku peserta didik berarti, seorang pendidik berhak untuk mengingatkan dan memberikan arahan kepada peserta didik yang kedapatan melakukan suatu tindakan tidak terpuji.

Berdasarkan hasil pembahasan di atas dapat disimpulkan sudah sesuai dengan teori yang ada. Bahwa untuk sikap sopan santun para peserta didik di MI Sunan Kalijogo Malang sudah cukup bagus. Akan tetapi masih ada sebagian saja peserta didik yang akhlaknya rendah akan tetapi hal itu dapat 
teratasi dengan baik, seperti bapak dan ibu guru selalu memberikan peringatan apabila menemui peserta didik yang bandel atau tidak menunjukkan etika yang bagus, pendekatan dan nasihat yang halus secara pribadi. Bisa dikatakan bahwa dengan diberikannya peringatan, nasihat dan pendekatan secara pribadi para peserta didik diharapkan agar ia selalu sadar dan mengingat bahwa apa yang dilakukannya merupakan perbuatan yang tidak baik untuk dilaksanakan.

\section{Penanaman Pendidikan Karakter Sopan Santun}

Perilaku santun menurut Andayani dan Majid (2012: 202) yaitu merupakan suatu tindakan dan ucapan yang tidak bertentangan dengan etika dan norma yang berlaku serta diwujudkan terhadap dirinya sendiri dan orang lain. Tujuan pendidikan karakter untuk taraf yang baik menurut Syafri (2012: 99) mengemukakan bahwa segenap proses kegiatan pendidikan yang berhubungan langsung dengan sikap sopan dan santun tanpa diimbangi dengan penerapan secara langsung, pembiasaan terhadap dirinya sendiri, maka bisa dikatakan proses pendidikan itu akan menjadi angan belaka, pada dasarnya adanya kegiatan pembiasaan rutin dalam proses kegiatan pendidikan diperlukan. Menurut Imron dalam penelitiannya (2014:4) menyatakan bahwa terdapat 18 karakter negativ yang direduksi dalam supervisi pembelajaran ialah: tidak agamis, curang, intoleran, indisipliner, malas, tidak kreatif, tidak demokratis, bergantung, masa bodoh, tidak punya rasa kebanggaan berbangsa, tidak cinta tanah air, tidak menghargai prestasi, tidak bersahabat, suka berkonflik/bertengkar, malas membaca, tidak peduli lingkungan, tidak punya kepedulian sosial dan tidak bertanggung jawab.

Berdasarkan pernyataan yang telah dipaparkan dapat dikatakan bahwa bentuk penanaman pendidikan karakter sopan santun peserta didik di MI Sunan Kalijogo Malang cara yang diimplementasikan untuk membentuk karakter yang mulia yakni dengan selalu membimbing para peserta didik untuk beretika sopan dan santun, mengarahkan peserta didik dan selalu melakukan kegiatan pembiasaan rutin yang dilaksanakan setiap pagi yakni sholat dhuha berjamaah, selalu bersalaman dengan bapak dan ibu guru sebelum masuk maupun keluar kelas ataupun bertemu pada saat diluar maupun didalam sekolah, diharapkan dengan adanya pembiasaan tersebut akan membentuk karakter sopan dan santun peserta didik yang mulia. Berdasarkan pembahasan yang telah dipaparkan sudah sesuai dengan teori yang telah dijabarkan, sehingga dapat disimpulkan bahwa bentuk penanaman pendidikan karakter sopan santun dengan memberikan contoh sikap teladan yang baik yakni selalu berjabat tangan ketika bertemu dengan bapak dan ibu guru, memakai pakaian yang rapi lengkap atributnya, pembiasaan rutin yakni ibadah sholat berjama'ah, selalu bertutur kata yang lembut baik kepada bapak ibu guru, orang tua, maupun sesama teman sebaya, ketika ia hendak masuk kelas selalu mengucapkan Assalamualaikum. Diharapkan dengan pemberian contoh sikap dan etika yang sopan dan santun para peserta peserta didik dapat mengikuti apa yang dicontohkan oleh bapak dan guru tersebut dan menerapkannya dalam kehidupannya.

\section{Faktor Penunjang Penanaman Pendidikan Karakter Sopan Santun}

Karakter merupakan ciri khas yang melekat pada diri individu yang mana antar individu satu dengan yang lainnya berbeda. Karakter sering dianggap sebagai bentuk perilaku yang menggambarkan hubungan seseorang dengan tuhan yang maha esa serta hubungan seseorang dengan lingkungan sekitarnya. Dengan demikian untuk dapat membentuk karakter luhur peserta didik maka, sebagai pendidik harus berupaya semaksimal mungkin memberikan suri tauladan yang baik, namun dalam pelaksanaannya terdapat faktor penunjang dan faktor lain yang menghambat jalannya implementasi dari pendidikan karakter yang sopan santun di sekolah. Upaya pengembangan pendidikan karakter peserta didik dapat dilakukan melaui banyak kegiatan yang mengandung nilai-nilai solidaritas. Nilai-nilai solidaritas tersebut menurut Imron (2017:7) meliputi bersikap ramah, toleran, mampu berkompromi, menjadi bersemangat untuk berbagi, memiliki jejaring sosial, membantu, bersemangat untuk memahami, menjadi empati, terbiasa, mengambil peluang, dan memberikan kenyamanan. Nilai-nilai solidaritas di atas kemudian diintegrasikan melalui berbagai kegiatan peserta didik sendiri yang terdiri dari seni, olahraga, kegiatan keagamaan, khusus kegiatan pengembangan bakat, kegiatan sosial, keterampilan kegiatan, kegiatan OSIS, dan kegiatan layanan kesehatan. Mengintegrasikan nilai solidaritas adalah prinsipal, wakil kepala sekolah dari urusan kemahasiswaan, guru, administrator dan dewan siswa. 
Adapun faktor penunjang dalam penanaman pendidikan karakter sopan santun di MI Sunan Kalijogo Malang yakni proses kegiatan belajar mengajar mata pelajaran Akidah Akhlak dibuat menyenangkan. Hal ini dibuktikan oleh adanya sarana prasarana yang mendukung, minat belajar yang tinggi, lingkungan kelas yang kondusif, metode pembelajaran yang bervariasi. Dengan demikian apabila beberapa aspek tersebut bisa terpenuhi dengan baik maka kegiatan belajar mengajar akan berjalan efektif dan efisien. Jadi implementasi pendidikan karakter akan terlaksana tepat sasaran. Menurut Yuliana dan Arikunto (2008:273) mengemukakan bahwa sarana pendidikan yang ada merupakan salah satu faktor penunjang tercapainya tujuan dari kegiatan pembelajaran yang ada dikelas. Sedangkan jika dibandingkan menurut Minarti (2011:251), mengemukakan bahwa sarana pendidikan merupakan semua perlengkapan yang digunakan selama proses kegiatan pembelajaran berlangsung seperti meja, kursi, kelas dan media pengajaran.

Berdasarkan hasil pembahasan yang telah dipaparkan sudah sesuai dengan teori yang ada bahwa yang menjadi faktor pendukung terlaksananya penanaman pendidikan karakter sopan santun pada mata pelajaran Akidah Akhlak di MI Sunan Kalijogo Malang yaitu: sarana pendidikan, prasarana pendidikan, minat belajar peserta didik yang begitu tinggi, suasana kelas kondusif , perhatian guru yang begitu tinggi, contoh sikap baik yang diberikan oleh seorang guru.

\section{Pengoptimalan Pendayagunaan Faktor Penunjang Penanaman Pendidikan Karakter Sopan Santun}

Pengoptimalan kegiatan pendidikan karakter di sekolah sangat penting baik bagi peserta didik maupun guru. Kegiatan tersebut diperlukan untuk menciptakan sumberdaya manusia yang unggul baik dibidang moral maupun akademik. Guna mengoptimalkan pendayagunaan faktor penunjang pendidikan karakter di MI Sunan Kalijogo Malang maka diperlukan dukungan dari seluruh warga sekolah dan lingkungan serta diperlukan sarana dan prasarana yang dapat menunjang penerapan program pendidikan karakter tersebut. Syafri (2012: 140) mengemukakan bahwa keteladanan peserta didik dapat diperoleh dari perilaku yang dicontohkan oleh guru, kepala sekolah dan tenaga adminitrasi sekolah. Sehingga baik guru, kepala sekolah dan tenaga administrasi sekolah sebaiknya selalu memberikan contoh sikap yang santun dan luhur saat berada di sekolah. Kunci dari pendidikan karakter adalah suri tauladan. Dengan suri tauladan yang baik serta adanya dukungan lingkungan masyarakat maupun sekolah maka seorang peserta didik akan mampu memperoleh keteladanan akidah, moral yang luhur, fisik yang kuat serta pengetahuan mental yang matang.

Berdasarkan pembahasan yang dijelaskan sudah sesuai dengan teori yang ada bahwa untuk mengoptimalkan pendayagunaan penanaman pendidikan karakter di MI Sunan Kalijaga Malang mengimplementasikan pendidikan karakter pada mata pelajaran Akidah Akhlak. Selain itu semua guru mata pelajaran harus tahu bagaimana mengarahkan keberhasilan pendidikan karakter peserta didik, guru harus memberikan contoh atau keteladanan perilaku yang baik terhadap peserta didik, membiasakan sholat dhuha berjama'ah di masjid, dalam hal kegiatan pembelajaran diawali dengan membaca doa bersama, membaca asmaul husna bersama.

\section{Faktor Kendala dalam Penanaman Pendidikan Karakter Sopan Santun}

Hasil penelitian yang ditemukan berhubungan dengan faktor kendala yang ditemui dalam penanaman pendidikan karakter sopan santun pada peserta didik melalui pembelajaran Akidah Akhlak di MI Sunan Kalijogo Malang, mendapati faktor kendala dalam mengimplementasikan pendidikan karakter, yaitu faktor lingkungan disekitar peserta didik yang kurang baik yang akan berpengaruh terhadap tingkah laku seseorang, karena lingkungan merupakan pendidikan utama yang akan ada hal positif dan negatifnya, keberagaman peserta didik, salah dalam memilih teman, penyalahgunaan media masa dan teknologi yang berdampak negativ bagi peserta didik, waktu disekolah yang terbatas serta faktor keluarga yang kebanyakan orangtuanya sibuk bekerja yang mengakibatkan anak tidak terurus atau terdidik dengan baik. Sehingga perlu kesabaran dan berkelanjutan untuk membangun dan menanamkan karakter peserta didik dengan menegakkan tata tertib peserta didik dan kegiatan-kegiatan disekolah, pembiasaan-pembiasaan budaya sekolah yang mencerminkan nilai karakter serta budi pakerti guru yang dapat dijadikan contoh bagi peserta didik sehingga mampu merubah karakter peserta didik itu sendiri. 
Jadi disini orang tua sangat berperan penting dalam pembentukan karakter anak dikarenakan salah satu fungsi utama keluarga itu sendiri yakni sebagai wadah untuk mendidik, mengasuh, mengembangkan kemampuan agar dapat menjalankan fungsinya dilingkungan sekitar. Damayanti (2014:78) berpendapat bahwa penanaman nilai karakter merupakan hal yang mendasari adanya penerapan pendidikan karakter di sekolah, namun sikap sopan santun, berbudi luhur, ramah tamah, selalu disiplin, dan mentaati peraturan, diperlukan agar implementasi pendidikan karakter dapat berjalan secara optimal. Berdasarkan hasil pembahasan yang telah dipaparkan sudah sesuai dengan teori bahwa faktor kendala dalam implementasi pendidikan karakter sopan santun di MI Sunan Kalijogo Malang salah satunya yaitu latar belakang setiap peserta didik berbeda-beda. sikap orang tua yang masih kurang dalam mendidik, lingkungan sekitar peserta didik baik yang ada diluar sekolah, kurangnya perhatian secara khusus beberapa guru terhadap perilaku peserta didik.

\section{Solusi dari Kendala Penanaman Pendidikan Karakter Sopan Santun}

Berdasarkan hasil penelitian yang dilakukan, bahwasanya solusi yang dilakukan dari kendala penanaman pendidikan karakter sopan santun peserta didik di MI Sunan Kalijogo Malang yakni menegur peserta didik yang masih sulit menerapkan etika sopan santun, Memberi nasihat tanpa melakukan kekerasan fisik yakni guru memberi nasihat kepada peserta didik yang tidak sopan santun terhadap perilakunya, mengadakan sosialisasi pada saat pengambilan raport dengan menekankan kepada wali murid bahwa jika berada disekolah harus memiliki sikap sopan santun yang tinggi, memberi hukuman yang sifatnya mendidik seperti menghafalkan surat pendek, selalu membiasakan kepada peserta didik untuk membaca doa jika mau masuk kelas ataupun keluar kelas, membiasakan menyapa bapak dan ibu guru baik diluar maupun didalam sekolah. Para guru juga harus mengambil andil dalam setiap kegiatan peserta didik yang dijalankan, memberikan motivasi kepada peserta didik agar terus berkembang, dan memberikan solusi jika ada kesulitan. Ini dimaksud pentingnya kehadiran orang tua atau guru untuk memantau aktivitas dan perkembangan peserta didik.

Selain juga harus mengambil andil dalam setiap peserta didik juga harus komitmen kepada diri sendiri bahwa posisinya adalah sebagai pendidik yang mana keteladanan dan kedisiplinannya sangat diperlukan untuk dicontoh peserta didik, seperti keluar dan masuk kelas sesuai waktu yang ditentukan, berpakaian rapi, izin saat tidak bisa masuk sekolah dan lain-lain.

Hal tersebut sesuai dengan yang disampaikan oleh Supriyono dan Ahmadi (1991:45) mengemukakan bahwa peran guru ini antara lain meliputi guru sebagai pendidik, pengajar, pembimbing, pelatih, penasihat, pembaharu, model dan teladan. Selaras dengan pendapatnya, Usman (2011:45) juga berpendapat bahwa guru berperan penting dalam upaya mengoptimalkan segala potensi yang dimiliki peserta didik. Berdasarkan hasil pembahasan yang telah dipaparkan sudah sesuai dengan teori bahwa untuk solusi yang dilakukan dari kendala penanaman pendidikan karakter sopan santun pada peserta didik di MI Sunan Kalijogo Malang yakni dengan memberi nasehat setiap peserta didik tanpa melakukan kekerasan fisik, selalu memberi hukuman kepada peserta didik yang sifatnya mendidik seperti hukuman menghafal ayat pendek yang terdapat di al-quran, memberitahu kepada peserta didik untuk membaca doa jika mau masuk ataupun keluar ruang kelasa, selalu menyapa bapak atau ibu guru, melaksanakan 5S (Senyum, Sapa, Salam, Sopan dan Santun).

\section{SIMPULAN}

Berdasarkan hasil penelitian dan pembahasan tentang implementasi pendidikan karakter sopan santun melalui pembelajaran akidah akhlak, maka dapat disimpulkan kegiatan belajar mengajar di MI Sunan Kalijaga Malang berjalan dengan lancar, efektif, dan inovatif. Pada pelaksanaannya guru selalu memiliki strategi sendiri guna meningkatkan pembelajaran dan peserta didik antusias dalam pembelajaran. Untuk keberhasilan pembelajaran guru menggunakan metode mengajar yakni ceramah, demonstrasi, dan berdiskusi. Selain strategi tersebut juga ditunjang dengan media pembelajaran yakni komponen suara dan komponen gambar contohnya LCD proyektor. Dengan demikian media-media yang digunakan sangat bermanfaat bagi peserta didik dalam pelaksanaan kegiatan belajar mengajar. 
Perilaku sopan santun peserta didik di MI Sunan Kalijogo Malang karakter sopan santun peserta didik sudah baik dan sudah ada pembentukan tinggal menambah. Perilaku adalah sebuah usaha guna mengubah sikap ke arah yang jauh lebih baik lagi dari sebelumnya. Perilaku sopan santun tidak terjadi dengan begitu saja melainkan dapat dipengaruhi oleh lingkungan sekitar maupun teman. Dapat dikatakan bahwa peran guru sangat diperlukan untuk melatih karakter peserta didik agar ia dapat menjadi pribadi baik ke depannya.

Bentuk penanaman pendidikan karakter sopan santun peserta didik di MI Sunan Kalijogo Malang yang dilakukan oleh Bapak dan Ibu Guru ialah memberikan contoh sikap yang mulia, memberi dorongan, dan membiasakan perilaku yang baik. Jadi diharapkan adanya pembiasaan yang baik dapat membentuk akhlak yang baik pula nantinya.

Faktor penunjang dalam pendidikan karakter sopan santun yang ada di MI Sunan Kalijogo Malang yakni dalam proses kegiatan belajar mengajar pada mata pelajaran akidah akhlak didukung oleh sarana dan prasarana kelas yang memadai dan menarik bagi peserta didik, untuk minat belajar peserta didik yang tinggi maka harus ditunjang juga dengan suasana kelas yang nyaman dan bersih.

Pengoptimalan pengajaran pendidikan karakter di sekolah sangat penting bagi peserta didik dan juga guru, bahwa untuk membentuk karakter peserta didik yang mulia bukan sesuatu usaha yang mudah untuk diimplementasikan, maka dari itu pihak sekolah hrus bisa bertanggungjawab persiapan dalam mengembangkan penanaman pendidikan karakter sopan santun di MI Sunan Kalijogo.

Untuk mengoptimalkan pendayagunaan faktor penunjang pendidikan karakter sopan santun pada peserta didik di MI Sunan Kalijogo Malang diantaranya yaitu: adanya dukungan kerja sama yang baik antara lingkungan dan warga sekolah, untuk kelengkapan sarana dan prasarana juga harus yang memadai sehingga penanaman pendidikan karakter yang telah diberikan oleh sekolah akan maksimal. Selanjutnya adalah tentang keteladanan moral dukungan orang tua peserta didik, baik itu kepada peserta didik ataupun kepada sekolah itu sendiri.

Faktor kendala yang ditemui dalam hal penanaman pendidikan karakter sopan santun pada peserta didik di MI Sunan Kalijogo Malang, yaitu adanya faktor lingkungan setiap harinya di sekitar peserta didik yang kurang baik, hal ini yang akan berpengaruh terhadap tingkah laku seorang peserta didik itu sendiri, karena lingkungan merupakan dasar atau pendidikan utama yang memiliki hal positif dan negatif, keberagaman peserta didik, salah dalam bergaul atau memilih teman, adanya penyalahgunaan media masa, dan juga teknologi yang berdampak negatif bagi perkembangan peserta didik.

Solusi yang bisa dilakukan dari adanya kendala penanaman pendidikan karakter sopan santun pada peserta didik MI Sunan Kalijogo Malang yakni dengan memberi nasihat yang bermanfaat dan membangun bagi peserta didik, hal ini dilakukan tanpa adanya perlakuan kekerasan fisik, dan juga memberi hukuman atau teguran berupa peringatan kepada peserta didik yang sifatnya mendidik seperti hukuman menghafal bacaan surat atau ayat pendek yang terdapat di Al-quran, perlunya memberitahu kepada peserta didik untuk selalu membiasakan membaca doa terlebih dahulu jika akan masuk ataupun keluar ruang kelas, selalu menyapa dan berjabat tangan kepada Bapak atau Ibu guru yang ada di sekolah.

\section{DAFTAR RUJUKAN}

Andayani, D. dan Majid, A. 2012. Pendidikan Karakter Perspektif Islam. Jakarta:Rajawali Pers.

Damayanti, D. 2014. Panduan Implementasi Pendidikan Karakter di Sekolah. Yogyakarta: Araska.

Imron, A. 2014. Integrasi Karakter Positif dan Reduksi Karakter Negatif dalam Supervisi Pembelajaran, (Online), (http://ap.fip.um.ac.id/wp-content/uploads/2015/04/03-Ali-Imron.pdf), Diakses tanggal 7 April 2020.

Imron, A. 2016. Coceptual Model Pupil Management With Balancing Competitive-Solidarity Value for the Preparation of the Caracter Generation Competitive and Social-Solidarity to Be Ready Demographic Bonus and The Best Economic Era, (Online), (http://coema.unm.ac.id/Proseding_International_Conference_on_ Educational_Management_and_Administration_COEMA_2016.pdf), Diakses tanggal 11 April 2020

Imron, A. 2017. Empirical Model Pupil Management Integrating With Balancing Competitive-Solidarity Value for the Preparation of Character Generation Competitive and Social-Solidarity to be Ready Demographic Bonus and the Best Economic Era, 6 (1). (Online), (http://centreofexcellence.net/J/JSS/Vol6/No1/JSSarticle1,6_1_ pp1-13.pdf), Diakses tanggal 11 April 2020. 
Minarti, S. 2011. Manajemen Sekolah: Mengelola Lembaga Pendidikan Secara Mandiri. Yogyakarta: Ar-Ruzz Media.

Suprahatiningrum, J. 2013. Strategi Pembelajaran Teori dan Aplikasi. Jogjakarta: Ar-Ruzz Media.

Supriyono, W. dan Ahmadi, A. 1991. Psikologi Belajar. Jakarta: Rineka Cipta.

Syafri, A. U. 2012. Pendidikan Karakter Berbasis Alqur'an. Jakarta:Rajawali Pers.

Usman, U. M. 2011. Menjadi Guru Professional. Bandung: Remaja Rosdakarya.

Yuliana, L. dan Arikunto, S. 2008. Manajemen Pendidikan. Yogyakarta: Aditya Media Bekerjasama dengan Fakultas Ilmu Pendidikan Universitas Negeri Yogyakarta.

Zuhriyah, N. 2007. Pendidikan Moral dan Budi Pakerti dalam Perspektif Perubahan. Jakarta: PT Bumi Aksara. 